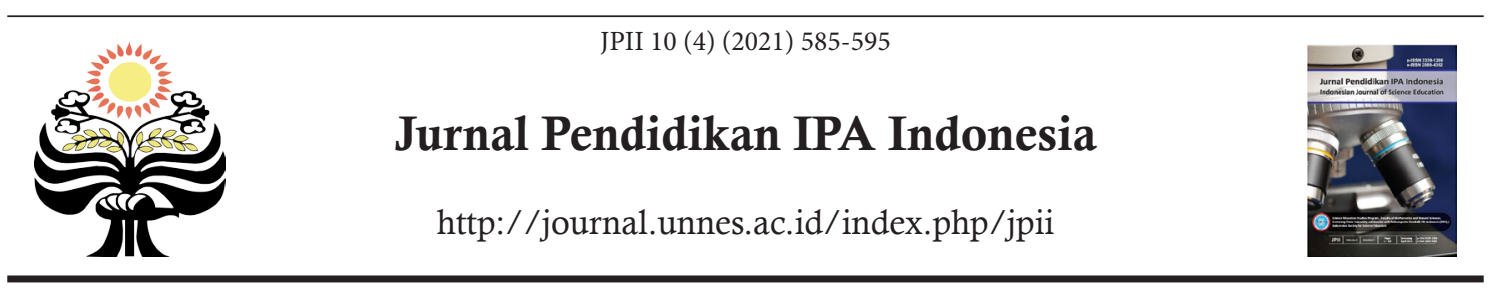

\title{
MULTIPLE SKILL LABORATORY ACTIVITIES: HOW TO IMPROVE STUDENTS' SCIENTIFIC COMMUNICATION AND COLLABORATION SKILLS
}

\author{
A. Malik ${ }^{* 1}$ and M. Ubaidillah ${ }^{2}$ \\ ${ }^{1}$ Department of Physics Education, Faculty of Tarbiyah and Teacher Training, \\ UIN Sunan Gunung Djati Bandung, Indonesia \\ ${ }^{2}$ Department of Biology Education, Faculty of Tarbiyah and Teacher Training, \\ IAIN Syekh Nurjati Cirebon, Indonesia
}

DOI: 10.15294/jpii.v10i4.31442

Accepted: August $1^{\text {st }} 2021$. Approved: December $2^{\text {th }} 2021$. Published: December $31^{\text {st }} 2021$

\begin{abstract}
This study aims to analyze the effects of experiment models and gender on scientific communication and collaboration skills. This study employed a quasi-experimental design consisting of five groups as control classes and five groups as experimental classes. The subject of this study was 327 students (168 students used HOT Lab and 159 used Multiple Skill; 69 Male and 258 Female from 18 to 22 years old) with heterogeneous skills and learning habits from five different universities representing four regions: Sumatra, Java, Kalimantan, and Sulawesi. The control class conducted activities based on the Higher-order Thinking Laboratory model, while the experimental class conducted activities based on the Multiple Skill Laboratory Activity Model. The data were collected by employing a validated instrument and were analyzed by employing a Multivariate test. This study shows that the experimental model has more significant influences on improving students' skills than gender. Specifically, the Multiple Skill Laboratory Activity Model (MSLAM) improves students' collaboration skills better than communication skills. MSLAM explores more activities to practice collaboration skills, e.g., brainstorming, exploration, and measurement, while the activities for practicing communication skills is depended on analysis and presentation only. This study also reveals that the experiment model and gender are not suitable for concurrent analysis. This study is expected to provide methods for further researchers to optimize students' scientific communication and collaboration skills. Furthermore, this study provides an overview for teachers to practice several thinking skills at one time.
\end{abstract}

(C) 2021 Science Education Study Program FMIPA UNNES Semarang

Keywords: collaboration skills; multiple skills laboratory; multivariate analysis; scientific communication skills

\section{INTRODUCTION}

The rapid distribution of information and easy access to information from various sources are characteristics of the 21st-century, including 21 st-century education. Nowadays, students can easily access various learning resources that may not be accessible to teachers. In addition, students and teachers can easily share their findings through various platforms, both free and paid. Therefore, additional skills are needed so that

*Correspondence Address

E-mail: adammalik@uinsgd.ac.id students and teachers can deliver their findings appropriately. Such skills are called Scientific Communication Skills (SCS), one of the crucial competencies in the 21st-century (Chung et al., 2016; Siddiq et al., 2016; Shin, 2018; Alpusari et al., 2019; Gordon \& Martin, 2019), and it contributes scientifically to be accepted in society. The SCS encourages students to deliver their facts and data-based arguments and explanations (Pehrson et al., 2016; Hansen et al., 2018; Grainger et al., 2019). Besides, SCS is necessary to explain various physics concepts and simplify the explanation of the complex research results (Dannels et al., 
2003; Saleh et al., 2017). In addition, nowadays, students are in the globalization era that demands to convey ideas to the public. However, communication skills have not received much attention, especially in the laboratory learning environment.

A study shows that communication skills consistently fail to be demonstrated by science students than analytical, technical, and problemsolving skills (Gray, 2005; Sari \& El Islami, 2020; Stieff \& DeSutter, 2021). Graduates do not consistently display communication skills when hiring (McInnis et al., 2000). Modern workplaces complain that science graduates cannot meet the requirements of good communication (Herok et al., 2013). Learning how to collaborate is rarely considered an educational outcome (LiebechLien \& Sjølie, 2021). Another study shows that practicing science communication skills in undergraduate candidates is beneficial to individuals and society (Besley \& Tanner, 2011). Students need to practice scientific communication to solve scientific and social problems (Bray et al., 2012), collaboration skills increase self-efficacy, and opportunities to work with overseas partners for preservice teachers (Hur et al., 2020).

Previous studies still generally investigate the issues and have not optimized the experimental learning. There have been several studies focused on developing learning strategies, methods, and approaches to improve HOTs (Corder, 1995; Woods et al., 2004; Rickles et al., 2009; Novita, 2010; Atasoy, 2013; Chen et al., 2013; HoškováMayerová, 2014; Kusumawati et al., 2015; Klochkova et al., 2016; Prahani et al., 2016; Patriot et al., 2018; Triana et al., 2019). In addition, the researchers also focused on improving the model of teaching (Spektor-Levy et al., 2008; Yuliardi, 2017; Lubis et al., 2018; Alpusari et al., 2019) and learning media (Yang \& Heh, 2007; Van Nuland et al., 2012; Elmas et al., 2013; Wang et al., 2015; Pehrson et al., 2016; Yuliardi, 2017; Triana et al., 2019) or evaluation (Ladyshewsky \& Gotjamanos, 1997; Susie et al., 1999; Hobgood et al., 2002; Dunbar et al., 2006; Harasym et al., 2008; Calhoun et al., 2010; Pehrson et al., 2016).

While SCS and other thinking skills are proved more effectively by employing experimental-based learning (Zhou et al., 2013; Ibnu \& Rahayu, 2020; Nuryantini et al., 2020), experimentbased learning and other experimental models involve students to observe phenomena, trace the causes, test hypotheses, interpret, analyze, and explain findings.

The experimental models enable students to practice SCS and the Collaborative Skills (CS) simultaneously demonstrated by an experimental activity that allows students to work in a group ( $\mathrm{Li}$ \& Adamson, 1992; Di Marco et al., 2009; Wang et al., 2015; Ardhyani \& Khoiri, 2017). Like SCS, CS is also necessary for the 21st-century (García, 2016) to facilitate students to collaborate even with strangers.

CS, in the same condition as SCS, still receives less attention in the learning process. Most schools still prioritize competition among students as an effort to improve their learning outcomes. As a result, there are often significant differences in the students' skills. However, several efforts to effectively practice CS have started to develop. At least, there are four significant scopes as the focus of CS development that are learning strategies (McCandliss et al., 2003; Khan, 2008; Sundari, 2008; Sinex \& Chambers, 2013; Walker \& Sampson, 2013; Luo, 2014; Warne, 2014), teaching model (Liu et al., 2011; Erika \& Prahani, 2017), learning media (Aydın, 2016; Ardhyani \& Khoiri, 2017; Rubini et al., 2018; Rosidah \& Rosdiana, 2019), and learning evaluation (Khan \& Saleh, 1997; McCandliss et al., 2003; Walker \& Sampson, 2013).

Research on CS frequently combines treatment for other skills: with critical thinking skills (Hughes et al., 2018), with creative thinking (Chang et al., 2016), with learning outcomes (García, 2016), and with argumentation skills and self-efficacy (Erika \& Prahani, 2017). However, research that constructs the combination of communication and collaboration skills is still rarely conducted. Therefore, this study aims to investigate experimental-based learning that trains and develops SCS and CS simultaneously.

Another problem that has been encountered, especially in experimental-based learning, is gender consequence. Stereotypes rooted in society believe that male students have better skills than female students as an extended assumption that men are better at working with technology than women (Crymble, 2016). Furthermore, the existence of gender does not always provide a significant difference in improving the learning outcome. According to Brodahl (2011), gender does not significantly affect writing practices. However, the students' different skills are dominated by their adaptability to the technology applied. In collaboration, gender differences are frequently employed to determine a group's task divisions, especially group works that require physical skills (Adolphus \& Omeodu, 2016). Students tend to be spectators and data writers (like a secretary) when this method is implemented during the experimental activities. This result will indirectly affect the students' readiness to be prospective 
teachers. Therefore, this study employs gender as a factor to evaluate the effects of gender on students' skills.

This study focuses on determining the simultaneous improvement of SCS and CS practiced by implementing two experimental models, HOT Lab and MSLAM. The study aims to investigate the readiness of each experimental model to practice two or more thinking skills simultaneously. The study is expected to propose a description of the readiness model and possibly provide a reflection to improve the model in the future. Thus, the learning process becomes more efficient and successfully prepares output or graduate profiles with superior skills. The researchers hypothesize that students who conduct experiments by adopting the MSLAM model will have better SCS and CS than those who employ the HOT Lab model. In addition, this study focuses on identifying the influences of gender on experiment-based learning. The assumption that male students are better than female students in terms of experimental activities psychologically influences students' and the teacher's point of view. Therefore, this study is expected to describe the effects of gender differences. The researchers hypothesize that there are no significant differences between male students and female students. The research questions of this study are 1) How do the HOT Lab Model and the MSLAM simultaneously affect the increase of SCS and CS?; 2) Does gender affect the simultaneous practices of SCS and CS?

\section{METHODS}

This study employed a quasi-experimental method that discussed the effects of the experimental model HOT Lab and MSLAM in simultaneously practicing SCS and CS (Ary et al., 2018). The experimental design is provided in Table 1 . Furthermore, gender was employed as a review factor to determine their effects on experimental learning, especially on practicing SCS and CS at one time.

Table 1. Experimental Design

\begin{tabular}{cllll}
\hline \multirow{2}{*}{ Class } & \multicolumn{2}{c}{ SCS } & \multicolumn{2}{c}{ CS } \\
\cline { 2 - 5 } & Ctrl. & Exp. & Ctrl. & Exp. \\
\hline A & A-C $C_{1}$ & A-X & A-C & A-X \\
B & A-C $_{1}$ & A-X & A-C $_{2}$ & A-X \\
C & A-C & A-X & A-C & A-X \\
D & A-C & A-X & A-C & A-X \\
E & A-C & A-X & A-C & A-X \\
Explanation: A: UIN Sunan Gunung Djati Bandung, B: UIN \\
Imam Bonjol Padang, C: UIN Alauddin Makasar, D: IAIN \\
Palangka Raya, E: IAIN Syekh Nurjati Cirebon
\end{tabular}

This study involved 327 students (168 students used HOT Lab and 159 used Multiple Skill; 69 Male and 258 Female from 18 to 22 years old), and they were divided into ten groups: five groups applied the MSLAM as the experimental class, and five groups applied the HOT Lab as the control class. All of the groups conducted experiments on the series-parallel circuit on electrical and elasticity. This research was conducted from May 2019 to July 2020 by practicing the HOT $\mathrm{Lab}$ and the MSLAM to physics education students from five universities representing four regions in Indonesia. They were Java (UIN Sunan Gunung Dajti Bandung and IAIN Syekh Nurjati Cirebon), Sumatera (UIN Imam Bonjol Padang), Kalimantan (IAIN Palangka Raya), and Sulawesi (UIN Alauddin Makasar). The students had heterogeneous-academic skills and laboratory experience. In each university, the students were divided into two groups: one group experimented by employing the HOT Lab model as the control class, and the other group experimented by employing the MSLAM model as the experimental class.

In this study, participants carried out experimental activities according to their respective practicum instructions. During the implementation, observations were made to obtain information about the skills of scientific collaboration and communication. In the end, participants were given a post-test to get information about the final skills of the participants. The assessment sheets were employed to collect data consisting of assessment of SCS and CS. The assessment rubric used was developed following modern learning. The rubric was feasible used according to five expert judgments. The SCS instruments consisted of three aspects: scientific writing, information representative, and knowledge presentation. Meanwhile, the CS instruments consisted of seven indicators: contribution, group work, responsibility, problem-solving, open-mindedness, respect, and group investigation skills. Five observers in each university filled the instruments based on a rubric with a range of $1-3$ or $1-4$ for several indicators. All of the instrument was validated by expert judgment and recommended used for measuring students' skills.

The students in the control class were experimented with 11 stages of the HOT Lab, while the students in the experiment class were experimented with 15 stages of MSLAM. HOT Lab stages consisted of real-world problems, experimental questions, alternative solutions, conceptual questions, prediction, tools and materials, exploration, measurement, data analysis, answering predictions, and presentation. On the other side, 
MSLAM stages consisted of orientation issues, brainstorming, alternative ideas, discussion, conceptual questions, predictions, equipment, exploration, measurement, processing data, analysis, conclusion, presentation, and evaluation.

MANOVA analysis was employed to determine the contribution of two types of experiments on the students' SCS and CS toward experimental activities as their course. MANOVA was chosen because it fits the research design in which there are two interrelated dependent va- riables: the practicum model and gender (Warne, 2014). Moreover, gender differences were employed as a review factor in the students' skills. The statistical significance of this research was 0.05 level in two-tailed hypothesis tests.

\section{RESULTS AND DISCUSSION}

The first analysis discusses the effects of an experimental model on the improvement of SCS and CS provided in Table 2.

Table 2. The Multivariate Test by Wilks' Lambda Method

\begin{tabular}{lccc}
\hline & Value & F & sig. \\
\hline UIN Sunan Gunung Djati Bandung & 0.472 & 1.867 & 0.00 \\
UIN Imam Bonjol Padang & 0.387 & 21.769 & 0.00 \\
UIN Alauddin Makasar & 0.353 & 26.529 & 0.00 \\
IAIN Palangka Raya & 0.460 & 16.171 & 0.00 \\
IAIN Syekh Nurjati Cirebon & 0.557 & 13.893 & 0.00 \\
\hline
\end{tabular}

Table 2 shows that the experimental model significantly influences SCS and CS, shown by a significant value of less than 0.05 . The subsequent analysis employed the Test of Between-
Subject Effects data in each skill group as presented in Figure 1. This analysis was conducted by referring to intercept and signification values.

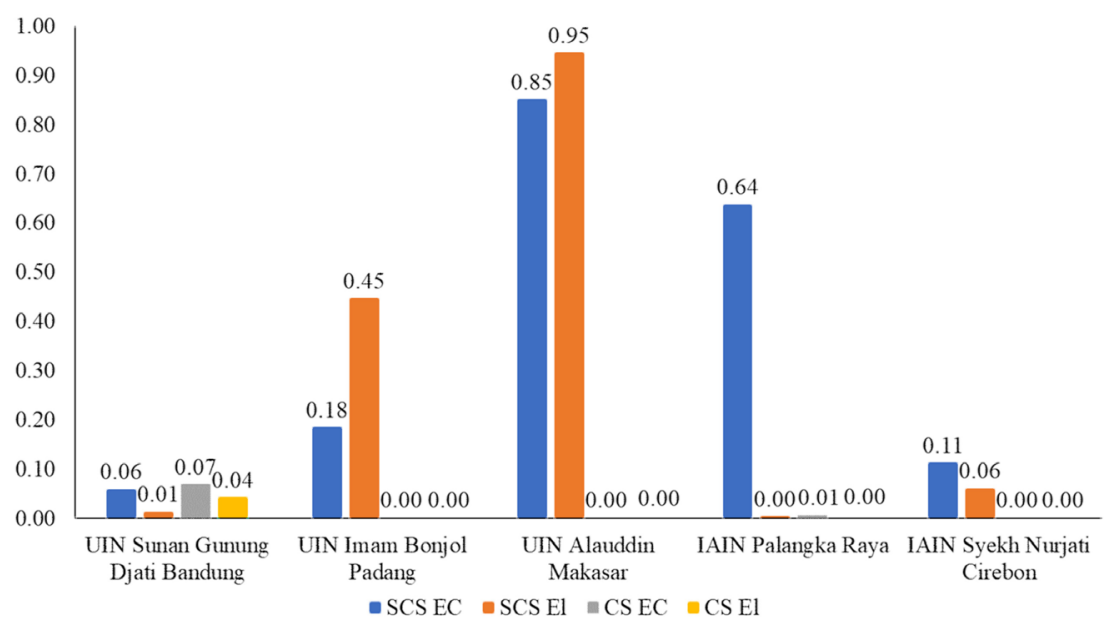

Figure 1. The Test of Between-Subject Effects - An Experimental Model (Intercept: 0.00)

Figure 1 indicates that the intercept value of every subject group is smaller than 0.05 , and it is interpreted as significant. This result indicates that there is an increase in SCS by ignoring the experiment influence. This result has not been finalized because it is compulsorily confirmed with significant values. The data reveal that only two subject groups have a lower value than 0.05 in SCS, and only three subject groups have a higher score than 0.05 in CS. Therefore, only two subject groups on SCS and seven groups on CS show a significant effect.

Gender is employed as a factor of analysis. Gender is assumed as a variable that can differentiate students' SCS and CS when conducting the experiments. Thus, the gender analysis is conducted similarly to the experimental model analysis. 
Table 3. The Multivariate Test by Wilks' Lambda Method

\begin{tabular}{lccc}
\hline & Value & F & sig. \\
\hline UIN Sunan Gunung Djati Bandung & 0.008 & 2078.854 & 0.000 \\
UIN Imam Bonjol Padang & 0.919 & 1.211 & 0.317 \\
UIN Alauddin Makasar & 0.882 & 1.934 & 0.117 \\
IAIN Palangka Raya & 0.915 & 1.281 & 0.289 \\
IAIN Syekh Nurjati Cirebon & 0.859 & 2.879 & 0.029 \\
\hline
\end{tabular}

In Table 3, statistics analysis proves that gender does not significantly contribute to the improvement of SCS and CS because the signifi-

cance values of the four subject groups are more than 0.05. Meanwhile, more calculation is proved

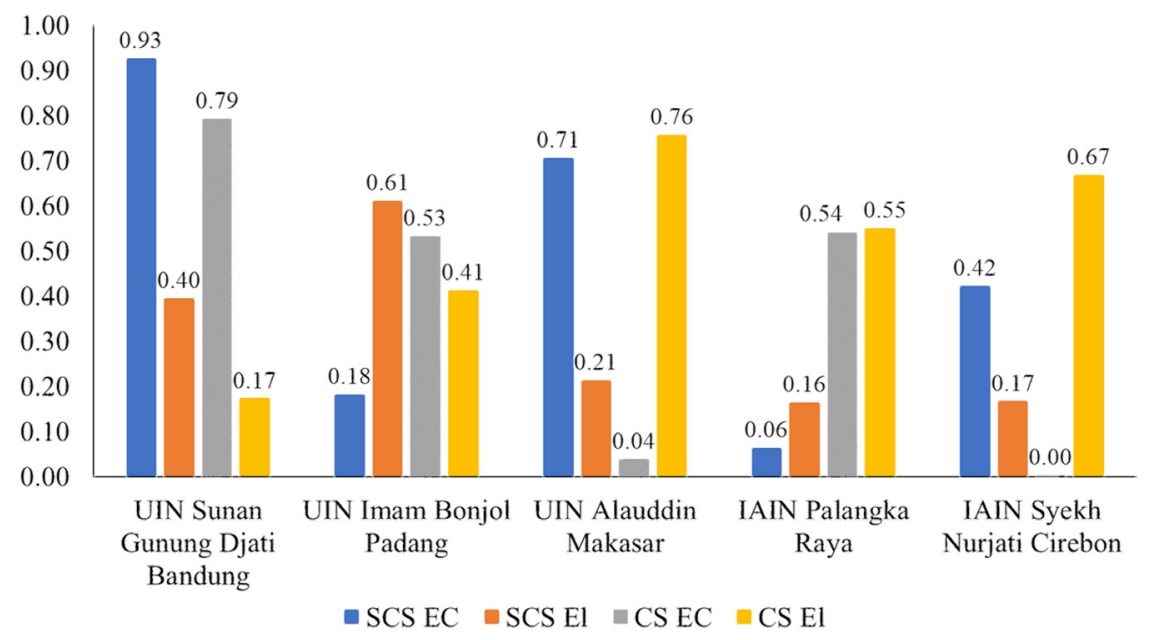

Figure 2. The Test of Between-Subject Effects-Gender (Intercept: 0.00)

Figure 2 shows that intercept values in both SCS and CS are smaller than 0.05. Therefore, it can be concluded that there is an increase in SCS and CS by ignoring the contribution of gender. Meanwhile, the column of sig. for SCS shows that gender does not significantly impact SCS. However, the value of sig. for CS shows that the sig. values of the two subject groups are lower than 0.05 , and it indicates that gender influences the increase of CS. The last analysis discusses the contribution of laboratory activities and gender to achieve SCS and CS. Table 4 shows that the pvalues of most experimental models are less than 0.05 .

Table 4. The Multivariate Test by Wilks' Lambda Method

\begin{tabular}{llccc}
\hline & & Value & F & sig. \\
\hline \multirow{2}{*}{ UIN Sunan Gunung Djati Bandung } & Experimental model & 0.005 & 3201.903 & 0.000 \\
& Gender & 0.943 & 0.958 & 0.437 \\
\multirow{2}{*}{ UIN Imam Bonjol Padang } & Experimental model & 0.381 & 21.952 & 0.000 \\
& Gender & 0.904 & 1.433 & 0.236 \\
UIN Alauddin Makasar & Experimental model & 0.895 & 1.679 & 0.167 \\
\multirow{2}{*}{ IAIN Palangka Raya } & Gender & 0.358 & 25.519 & 0.000 \\
& Experimental model & 0.460 & 15.876 & 0.000 \\
\multirow{2}{*}{ IAIN Syekh Nurjati Cirebon } & Gender & 0.915 & 1.257 & 0.298 \\
& Experimental model & 0.555 & 13.853 & 0.000 \\
& Gender & 0.854 & 2.940 & 0.026 \\
\hline
\end{tabular}


It shows that the experimental models can significantly affect the SCS and CS. Meanwhile, the significance values of the gender aspect are mostly greater than 0.05 , and it indicates that gender does not significantly influence the increase of SCS and CS.

The test results of between-subject effects in Table 5 show that, overall, the students' SCS and CS increase without considering the influence of the experimental model. Furthermore, the results show that gender has a small intercept value of 0.05 . Considering the contribution of the experimental model and gender, the SCS and CS insignificantly increase as indicated by the average scores of significance values in exp.: 0.24 for SCS and 0.08 for CS. Meanwhile, gender influences SCS by 0.39 and CS by 0.29 . However, it is stated that in SCS, the experimental model is more influential than gender.

Table 5. The Test of Between-Subject Effects-Integrated Analysis

\begin{tabular}{|c|c|c|c|c|c|c|c|}
\hline \multirow{2}{*}{ Subject Groups } & \multirow{2}{*}{ Content } & \multicolumn{3}{|c|}{ SCS } & \multicolumn{3}{|c|}{ CS } \\
\hline & & Intercept & Exp. & Gender & Intercept & Exp. & Gender \\
\hline \multirow{2}{*}{$\begin{array}{l}\text { UIN Sunan Gunung } \\
\text { Djati Bandung }\end{array}$} & $\begin{array}{l}\text { Electric } \\
\text { Circuit }\end{array}$ & 0.000 & 0.000 & 0.303 & 0.000 & 0.063 & 0.632 \\
\hline & Elasticity & 0.000 & 0.016 & 0.548 & 0.000 & 0.057 & 0.243 \\
\hline \multirow{2}{*}{$\begin{array}{l}\text { UIN Imam Bonjol } \\
\text { Padang }\end{array}$} & $\begin{array}{l}\text { Elelctric } \\
\text { Circuit }\end{array}$ & 0.000 & 0.172 & 0.169 & 0.000 & 0.000 & 0.503 \\
\hline & Elasticity & 0.000 & 0.442 & 0.278 & 0.000 & 0.000 & 0.190 \\
\hline \multirow{2}{*}{$\begin{array}{l}\text { UIN Alauddin } \\
\text { Makasar }\end{array}$} & $\begin{array}{l}\text { Electric } \\
\text { Circuit }\end{array}$ & 0.000 & 0.723 & 0.886 & 0.000 & 0.051 & 0.000 \\
\hline & Elasticity & 0.000 & 0.211 & 0.826 & 0.000 & 0.614 & 0.000 \\
\hline \multirow{2}{*}{ IAIN Palangka Raya } & $\begin{array}{l}\text { Elelctric } \\
\text { Circuit }\end{array}$ & 0.000 & 0.599 & 0.064 & 0.000 & 0.006 & 0.473 \\
\hline & Elasticity & 0.000 & 0.002 & 0.117 & 0.000 & 0.000 & 0.528 \\
\hline \multirow{2}{*}{$\begin{array}{l}\text { IAIN Syekh Nurjati } \\
\text { Cirebon }\end{array}$} & $\begin{array}{l}\text { Electric } \\
\text { Circuit }\end{array}$ & 0.000 & 0.124 & 0.469 & 0.000 & 0.000 & 0.003 \\
\hline & Elasticity & 0.000 & 0.069 & 0.192 & 0.000 & 0.000 & 0.420 \\
\hline
\end{tabular}

The study results indicate that the experimental model has significant effects on improving students' SCS and CS simultaneously. According to Liu (2011) and Warne (2014), a significancevalue less than 0.05 indicates that the independent variables (the experimental model) bring significant impacts on the dependent variables (SCS and CS) with the level of confidence is $95 \%$. Furthermore, these results are supported by previous studies that show the effects of the experimental model on SCS (Walker \& Sampson, 2013; Aydın, 2016; Malik et al., 2018; Sapriadil et al., 2018) and CS (Sinex \& Chambers, 2013; Zakwandi et al., 2020). Therefore, these results show that the SCS and CS can be simultaneously improved through one laboratory activity, the Multiple Skill Laboratory Activity Model (MSLAM).

Table 3 shows the limitation of MSLAM and HOT Lab models, and it reveals that only $20 \%$ of the subject group reach the target. However, it can still be stated that there is a difference in the value of SCS and CS by ignoring the type of laboratory activity. Many factors cause this condition, and one of them is learning activities as Rubini et al. (2018) prove that monotonous learning activities are difficult to increase the students' skills. Thus, the solution is presenting a variety of activities and providing the students with a challenge. Furthermore, most Indonesian school laboratories have not been optimized. The condition brings several harmful impacts because the experimental activities always require habituation. In addition, another finding reveals that the students have different skills to conduct different topics of an experiment. The significant average of electrical circuit content is 0.3684 , and no subject group has a significant effect.

Meanwhile, the average significance of the elasticity topic is 0.2936 , shown by two influential subject groups. This difference proposes the idea that students have some constraints on conducting experiments on electrical circuits. Rosidah \& Rosdiana (2019) state that students in traditional schools in Indonesia consider the electricity topic 
less desirable and challenging to learn. However, the students consider elasticity topics easier to learn. Furthermore, the study result shows that CS has a more significant increase than SCS. This finding is similar to the study by Nurafiah et al. (2018), who prove that students' CS increases more highly than their critical thinking, creativity, and communication skills. The correlation test by employing the $\mathrm{R}^{2}$ value indicates the correlation between dependent and independent variables. The test shows that SCS on the electrical circuit topic has an $\mathrm{R}^{2}$ value of 0.0316 , the value of SCS on elasticity topic is 0.1512 , the value of CS on electrical circuit topic is 0.2512 , and the value of CS on elasticity topic is 0.3542 . Thus, it can be inferred that the correlation is relatively low (Howarth, 2017).

Learning design in MSLAM builds students' knowledge through social interaction. This is following the learning characteristics proposed by Vygotsky that in a learning process students must actively build knowledge. Collaborative activities and scientific communication that emphasize high social interaction are expected to optimize students' thinking skills. Contextual physics phenomena allow students to learn from new things that are close to life. In addition, the design of learning activities that emphasize the completion of certain tasks is following the main principles of the learning model developed by Vygotsky, which is Scaffolding. (Smagorinsky, 2018; Shvarts \& Bakker, 2019).

The data of gender differences of this study show that gender differences do not significantly influence the improvement of students' SCS and CS. It indicates that male and female students have an equal opportunity to achieve competence in experiment-based learning. This result confirms those of previous research deploying that gender does not significantly result in differences. Even so, women have better grades than men (Shi et al., 2015). Nevertheless, Shi et al. (2015) argue that students can still work together in conducting experiments through the best possible disposition. However, there are several considerations. For example, female students tend to garrulously work in a minority group while male students are talkative when they work independently. Shi et al. (2015) add those female students are more likely to play a supporting role while male students play a prominent role when collaborating in experimental activities. Furthermore, the results of R2 show very weak correlations between gender and SCS on electrical circuits topic by 0.02 , gender and SCS on elasticity topic by 0.13 , between gender and CS on the electrical current topic by 0.04 , and between gender and CS on elasticity topic by 0.01 .

The integrated analysis is conducted by employing two independent variables in which one factor significantly influences and the other factor does not. This condition indicates that this factor analysis is unsuitable because it leads to inconsistent significance values possibly caused by several variables. The experimental model is an external factor that can be managed in specific ways, while gender is an internal factor that cannot be controlled. However, indicators that are likely influenced by genders, such as motivation and perspective, can be managed. Hence, by using MSLAM, we can improve students' CS better than SCS simultaneously. While the result also shows that students' SCS cannot be improved optimally.

The limitations of this research are conducting subject sampling with high levels of heterogeneity and broad scope. Besides, the constraints of this study relate to the level of preliminary skills and behavior in each subject group. The instrument of this study is the performance appraisal to measure SCS and CS, while the assessment process is more complex. Therefore, further research can investigate the development of evaluation instruments that precisely measure the effects of conducting laboratory activities to improve more skills at one time. Therefore, it is expected that further research will provide more specific measurement results.

\section{CONCLUSION}

Learning based-experiment by employing the Multiple Skill Laboratory Activity Model (MSLAM) can positively impact the HOT Lab. Overall, the communication and collaboration skills improve after conducting the experimental model. The analysis results reveal that the experimental aspect shows more significant impacts on improving scientific communication and collaboration skills than gender. Furthermore, the improved collaboration skills are better than scientific communication skills. Therefore, MSLAM and HOT Lab are better at improving collaboration skills. The limitations of this study include a sampling of heterogeneity of subject groups, the habits of the experimental model performed by each subject, and assessment instruments employed to measure skills of scientific communication and collaboration. These limitations propose that the implementation of experimental model-based 
learning requires empowerment. The students have a more adaptive learning experience and are compatible with the current conditions. Moreover, further research on developing an appropriate assessment instrument needs to consider.

\section{ACKNOWLEDGEMENTS}

This research received financial support from the Ministry of Religion of the Republic of Indonesia through the Directorate General of Islamic Education Contract Number 191020000027424 through the 1967 Grant of 2019 concerning Recipients of Global/International Applied Research Assistance for Fiscal Year 2019 to facilitate the funding of this research.

\section{REFERENCES}

Adolphus, T., \& Omeodu, D. (2016). Effects of Gender and Collaborative Learning Approach on Students' Conceptual understanding of Electromagnetic Induction. Journal of Curriculum and Teaching, 5(1), 78-86.

Alpusari, M., Mulyani, E. A., Putra, Z. H., Widyanthi, A., \& Hermita, N. (2019, November). Identifying Students' Scientific Communication Skills on Vertebrata Organs. In Journal of Physics: Conference Series (Vol. 1351, No. 1, p. 012070). IOP Publishing.

Ardhyani, S., \& Khoiri, N. (2017, March). Project based learning multi life skill for collaborative skills and technological skills of senior high school students. In Journal of Physics: Conference Series (Vol. 824, No. 1, p. 012010). IOP Publishing.

Ary, D., Jacobs, L. C., Irvine, C. K. S., \& Walker, D. (2018). Introduction to research in education. Cengage Learning.

Atasoy, Ş. (2013). Effect of writing-to-learn strategy on undergraduates' conceptual understanding of electrostatics. The Asia-Pacific Education Researcher, 22(4), 593-602.

Aydın, G. (2016). Impacts of Inquiry-Based Laboratory Experiments on Prospective Teachers' Communication Skills. International Online Journal of Educational Sciences.

Besley, J. C., \& Tanner, A. H. (2011). What science communication scholars think about training scientists to communicate. Science Communication, 33(2), 239-263.

Bray, B., France, B., \& Gilbert, J. K. (2012). Identifying the essential elements of effective science communication: What do the experts say?. International Journal of Science Education, Part B, 2(1), 23-41.

Brodahl, C., Hadjerrouit, S., \& Kristian Hansen, N. (2011). Collaborative writing with web 2.0 technologies: Education students' perceptions.
Journal of Information Technology Education: Innovations in Practice, 10, 073-103.

Calhoun, A. W., Rider, E. A., Peterson, E., \& Meyer, E. C. (2010). Multi-rater feedback with gap analysis: an innovative means to assess communication skill and self-insight. Patient education and counseling, 80(3), 321-326.

Chang, J. W., Wang, T. I., Lee, M. C., Su, C. Y., \& Chang, P. C. (2016, July). Impact of Using Creative Thinking Skills and Open Data on Programming Design in a Computer-Supported Collaborative Learning Environment. In 2016 IEEE 16th International Conference on Advanced Learning Technologies (ICALT) (pp. 396-400). IEEE.

Chen, C. H., Chung, M. Y., \& Wu, W. C. V. (2013). The effects of faded prompts and feedback on college students' reflective writing skills. The Asia-Pacific Education Researcher, 22(4), 571-583.

Chung, Y., Yoo, J., Kim, S. W., Lee, H., \& Zeidler, D. L. (2016). Enhancing Students'communication Skills In The Science Classroom Through Socioscientific Issues. International Journal of Science and Mathematics Education, 14(1), 1-27.

Corder, P. R. (1995). U.S. Patent No. 5,387,104. Washington, DC: U.S. Patent and Trademark Office.

Crymble, A. (2016). Identifying and removing gender barriers in open learning communities: The programming historian. Blended Learning in Practice, 2016(July 2012), 49-60.

Dannels, D. P., Anson, C. M., Bullard, L., \& Peretti, S. (2003). Challenges in learning communication skills in chemical engineering. Communication Education, 52(1), 50-56.

Di Marco, S., Maneira, A., Ribeiro, P., \& Maneira, M. J. P. (2009). Blended-learning in Science and Technology. A collaborative project-based course in experimental physics. e-Learning $\mathrm{Pa}$ pers, www. elearningpapers. eu, (16), 1-14.

Dunbar, N. E., Brooks, C. F., \& Kubicka-Miller, T. (2006). Oral communication skills in higher education: Using a performance-based evaluation rubric to assess communication skills. Innovative Higher Education, 31(2), 115-128.

Elmas, R., Akın, F. N., \& Geban, Ö. (2013). Ask a scientist website: trends in chemistry questions in Turkey. The Asia-Pacific Education Researcher, 22(4), 559-569.

Erika, F., \& Prahani, B. K. (2017). Innovative chemistry learning model to improve argumentation skills and self-efficacy. IOSR Journal of Research \& Method in Education (IOSRJRME), 7(1), 62-68.

García, C. (2016). Project-based learning in virtual groups-collaboration and learning outcomes in a virtual training course for teachers. ProcediaSocial and Behavioral Sciences, 228, 100-105.

Gordon, V., \& Martin, D. (2019). The 21st-Century CEO: Intrinsic attributes, worldview, and communication capabilities. Journal of Leadership \& Organizational Studies, 26(2), 141-149. 
Grainger, P. R., Christie, M., \& Carey, M. (2019). Assessing written communication skills using a Continua Model of a Guide to Making Judgments (GTMJ). Journal of University Teaching \& Learning Practice, 16(2), 10-15.

Gray, F. E., Emerson, L., \& MacKay, B. (2005). Meeting the demands of the workplace: Science students and written skills. Journal of science education and technology, 14(4), 425-435.

Hansen, S. G., Carnett, A., \& Tullis, C. A. (2018). Defining early social communication skills: A systematic review and analysis. Advances in $\mathrm{Neu}$ rodevelopmental Disorders, 2(1), 116-128.

Harasym, P. H., Woloschuk, W., \& Cunning, L. (2008). Undesired variance due to examiner stringency/leniency effect in communication skill scores assessed in OSCEs. Advances in Health Sciences Education, 13(5), 617-632.

Herok, G. H., Chuck, J. A., \& Millar, T. J. (2013). Teaching and evaluating graduate attributes in science based disciplines. Creative Education, 4(07), 42-47.

Hobgood, C. D., Riviello, R. J., Jouriles, N., \& Hamilton, G. (2002). Assessment of communication and interpersonal skills competencies. Academic Emergency Medicine, 9(11), 1257-1269.

Hošková-Mayerová, Š. (2014). The effect of language preparation on communication skills and growth of students' self-confidence. ProcediaSocial and Behavioral Sciences, 114, 644-648.

Howarth, R. J. (2017). r2 (r-squared, R-squared, coefficient of determination) The square of the product-moment correlation coefficient; a measure of the goodness-of-fit of a regression.

Hughes, E. S., Bradford, J., \& Likens, C. (2018). Facilitating collaboration, communication, and critical thinking skills in physical therapy education through technology-enhanced instruction: A case study. TechTrends, 62(3), 296-302.

Hur, J. W., Shen, Y. W., \& Cho, M. H. (2020). Impact of intercultural online collaboration project for pre-service teachers. Technology, Pedagogy and Education, 29(1), 1-17.

Ibnu, S., \& Rahayu, S. (2020). The effectiveness of new inquiry-based learning (NIBL) for improving multiple higher-order thinking skills (M-HOTS) of prospective chemistry teachers. The Effectiveness of New Inquiry-Based Learning (NIBL) for Improving Multiple Higher-Order Thinking Skills (M-HOTS) of Prospective Chemistry Teachers, 9(3), 1309-1325.

Khan, S. (2008). Shrinkage estimators of intercept parameters of two simple regression models with suspected equal slopes. Communications in Statistics-Theory and Methods, 37(2), 247-260.

Khan, S., \& Saleh, A. K. (1997). Shrinkage Pre-Test Estimator of the Intercept Parameter for a Regression Model with Multivariate Student-t Errors. Biometrical Journal, 39(2), 131-147.

Klochkova, O., Komochkina, E., \& Mustafina, A. (2016). "Triad" strategy as an effective way of developing professional communication skills of physics and mathematics students. ProcediaSocial and Behavioral Sciences, 236, 271-276.

Kusumawati, I., Marwoto, P., \& Linuwih, S. (2015, September). Implementation multi representation and oral communication skills in Department of Physics Education on Elementary Physics II. In AIP Conference Proceedings (Vol. 1677, No. 1, p. 040017). AIP Publishing LLC.

Ladyshewsky, R., \& Gotjamanos, E. (1997). Communication skill development in health professional education: the use of standardized patients in combination with a peer assessment strategy. Journal of allied health, 26(4), 177.

Li, A. K., \& Adamson, G. (1992). Gifted secondary students' preferred learning style: Cooperative, competitive, or individualistic?. Journal for the Education of the Gifted, 16(1), 46-54.

Liebech-Lien, B., \& Sjølie, E. (2020). Teachers' conceptions and uses of student collaboration in the classroom. Educational Research, 1-17.

Liu, C., Bathke, A. C., \& Harrar, S. W. (2011). A nonparametric version of Wilks' lambda-Asymptotic results and small sample approximations. Statistics \& probability letters, 81(10), 15021506.

Lubis, N., Lubis, A., \& Ashadi, R. I. (2018). Integrating teaching models to enhance EFL students' interpersonal communication skill and creativity. International Journal of Education and Literacy Studies, 6(4), 129-137.

Luo, W. H. (2014). An exploration of professional development programs for teachers of collaborative teaching of EFL in Taiwan: A case study. The Asia-Pacific Education Researcher, 23(3), 403-412.

Malik, A., Setiawan, A., Suhandi, A., Permanasari, A., \& Sulasman, S. (2018). HOT lab-based practicum guide for pre-service physics teachers. In IOP Conference Series: Materials Science and Engineering (Vol. 288, No. 1, p. 012027). IOP Publishing.

McCandliss, B. D., Kalchman, M., \& Bryant, P. (2003). Design experiments and laboratory approaches to learning: Steps toward collaborative exchange. Educational Researcher, 32(1), 14-16.

Novita, N. (2010). Pentingnya Komunikasi Verbal Dalam Proses Pembelajaran (Kajian Perspektif Komunikasi Efektif Pada Pembelajaran). Manajemen Informatika, 2(1), 13-18.

Nurafiah, V., Utari, S., \& Liliawati, W. (2018). Profil Keterampilan Abad 21 Siswa SMA pada Project Based Learning (PjBL) Materi Tegangan Permukaan. WaPFi (Wahana Pendidikan Fisika), 4(2), 134-140.

Nuryantini, A. Y., Fajriah, H. N., Zakwandi, R., \& Nuryadin, B. W. (2020, June). Simple harmonic motion experiments with the accelerometer sensor on a smartphone: Improving the problem solving-ability. In Journal of Physics: Conference Series (Vol. 1572, No. 1, p. 012058). IOP Publishing. 
Patriot, E. A., Suhandi, A., \& Chandra, D. T. (2018, May). Optimize scientific communication skills on work and energy concept with implementation of interactive conceptual instruction and multi representation approach. In Journal of Physics: Conference Series (Vol. 1013, No. 1, p. 012029). IOP Publishing.

Pehrson, C., Banerjee, S. C., Manna, R., Shen, M. J., Hammonds, S., Coyle, N., ... \& Bylund, C. L. (2016). Responding empathically to patients: Development, implementation, and evaluation of a communication skills training module for oncology nurses. Patient education and counseling, 99(4), 610-616.

Prahani, B. K., Limatahu, I., Winata, S. W., Yuanita, L., \& Nur, M. (2016). Effectiveness of physics learning material through guided inquiry model to improve student's problem solving skills based on multiple representation. International Journal of Education and Research, 4(12), 231244.

Rickles, N. M., Tieu, P., Myers, L., Galal, S., \& Chung, V. (2009). The impact of a standardized patient program on student learning of communication skills. American journal of pharmaceutical education, 73(1), 9-15.

Rosidah, K., \& Rosdiana, L. (2019). Efektivitas Kit Rangkaian Listrik Sebagai Media Pembelajaran Untuk Meningkatan Hasil Belajar Siswa SMP. PENSA: E-Jurnal Pendidikan Sains, 7(1), $5-9$.

Rubini, B., Suhartoyo, H., \& Permanasari, A. (2018). Apakah inkuiri ilmiah berbasis investigasi kelompok dapat meningkatkan kerja ilmiah dan literasi sains siswa?. Jurnal Inovasi Pendidikan IPA, 4(2), 149-157.

Saleh, M., Al Barghuthi, N., \& Baker, S. (2017, October). Innovation in education via problem based learning from complexity to simplicity. In 2017 International Conference on New Trends in Computing Sciences (ICTCS) (pp. 283-288). IEEE.

Sapriadil, S., Setiawan, A., Suhandi, A., Malik, A., Safitri, D., Lisdiani, S. A. S., \& Hermita, N. (2018, May). Optimizing students' scientific communication skills through higher order thinking virtual laboratory (HOTVL). In Journal of Physics: Conference Series (Vol. 1013, No. 1, p. 012050). IOP Publishing.

Sari, I., \& El Islami, R. (2020). The Effectiveness of Scientific Argumentation Strategy towards the Various Learning Outcomes and Educational Levels Five Over the Years in Science Education. Journal of Innovation in Educational and Cultural Research, 1(2), 52-57.

Shi, W. Z., He, X., Wang, Y., \& Huan, W. (2015). Effects of lab group sex composition on physics learning. Eurasia Journal of Mathematics, Science and Technology Education, 11(1), 87-92.

Shin, D. (2018). Empathy and embodied experience in virtual environment: To what extent can virtual reality stimulate empathy and embodied experience?. Computers in Human Behavior, 78, 64-73.

Shvarts, A., \& Bakker, A. (2019). The early history of the scaffolding metaphor: Bernstein, Luria, Vygotsky, and before. Mind, Culture, and Activity, 26(1), 4-23.

Siddiq, F., Scherer, R., \& Tondeur, J. (2016). Teachers' emphasis on developing students' digital information and communication skills (TEDDICS): A new construct in 21st century education. Computers \& Education, 92, 1-14.

Sinex, S. A., \& Chambers, T. L. (2013). Developing online collaboration skills in the general Chemistry laboratory. Journal of Chemical Education, 90(9), 1244-1246.

Smagorinsky, P. (2018). Is Instructional Scaffolding Actually Vygotskian, and Why Should It Matter to Literacy Teachers?. Journal of Adolescent \& Adult Literacy, 62(3), 253-257.

Spektor-Levy, O., Eylon, B. S., \& Scherz, Z. (2008). Teaching communication skills in science: Tracing teacher change. Teaching and Teacher Education, 24(2), 462-477.

Stieff, M., \& DeSutter, D. (2021). Sketching, not representational competence, predicts improved science learning. Journal of Research in Science Teaching, 58(1), 128-156.

Sundari, R. (2008). Evaluasi pemanfaatan laboratorium dalam pembelajaran biologi di Madrasah Aliyah Negeri Sekabupaten Sleman. Jurnal Penelitian dan Evaluasi Pendidikan, 12(2), 196212.

Triana, M., \& Zubainur, C. M. (2019). Students' Mathematical Communication Ability through the Brain-Based Learning Approach Using Autograph. Journal of Research and Advances in Mathematics Education, 4(1), 1-10.

Van Nuland, M., Van den Noortgate, W., van der Vleuten, C., \& Jo, G. (2012). Optimizing the utility of communication OSCEs: omit stationspecific checklists and provide students with narrative feedback. Patient education and counseling, 88(1), 106-112.

Walker, J. P., \& Sampson, V. (2013). Argument-driven inquiry: Using the laboratory to improve undergraduates' science writing skills through meaningful science writing, peer-review, and revision. Journal of Chemical Education, 90(10), 1269-1274.

Wang, J., Guo, D., \& Jou, M. (2015). A study on the effects of model-based inquiry pedagogy on students' inquiry skills in a virtual physics lab. Computers in Human Behavior, 49, 658-669.

Warne, R. T. (2014). A primer on multivariate analysis of variance (MANOVA) for behavioral scientists. Practical Assessment, Research \& Evaluation, 19.

Woods, J., Kashinath, S., \& Goldstein, H. (2004). Effects of embedding caregiver-implemented teaching strategies in daily routines on children's communication outcomes. Journal of 
Early Intervention, 26(3), 175-193.

Yang, K. Y., \& Heh, J. S. (2007). The impact of internet virtual physics laboratory instruction on the achievement in physics, science process skills and computer attitudes of 10th-grade students. Journal of Science Education and Technology, 16(5), 451-461.

Yuliardi, R. (2017, September). Mathematics Learning Assisted Geogebra using Technologically Aligned Classroom (TAC) to Improve Communication Skills of Vocasional High School Student. In Journal of Physics: Conference Series (Vol. 895 , No. 1, p. 012156). IOP Publishing.
Zakwandi, R., Yuningsih, E. K., \& Setya, W. (2020). Implementasi Pembelajaran Berbasis Praktikum Pada Konsep Taraf Intensitas Bunyi untuk Meningkatkan Penguasaan Konsep Peserta Didik. Jurnal Penelitian Pembelajaran Fisika, 11(1), 75-82.

Zhou, Q., Huang, Q., \& Tian, H. (2013). Developing students' critical thinking skills by task-based learning in chemistry experiment teaching. Creative Education, 4(12), 40-45. 